\title{
Development of luminescent serum for diagnostics of animal bacillus anthracix agent
}

\author{
Albert K. Galiullin ${ }^{1 *}$, Iva I. Zadorina ${ }^{1}$, Elmira N. Mustafina ${ }^{2}$, Timur R. Mustafin ${ }^{2}$ \\ ${ }^{1}$ Kazan State Academy of Veterinary Medicine named after N.E. Bauman, Kazan, 420029, Russia \\ ${ }^{2}$ Federal Center for Toxicological, Radiation and Biological Safety, Scientific town-2, Kazan, 420075, Russia
}

\begin{abstract}
The purpose of the study was to obtain luminescent serum based on highly purified anthracoid globulins to diagnose anthrax agents in animals. To date, there are plenty diagnostic agents that allow rapid and accurate diagnostics of infectious diseases of animals. One of them is the luminescent microscopy of the fluorescent antibody method, which is used as an express method and provides for diagnostics within 35 hours. Hyperimmune serum globulins prepared on two types of antigens - protective from strain 55 (VNIIVViM) and capsular from Lange-2 strain at five-fold scheme of introduction of these antigens - were used to make luminescent anthracoid serum. The luminescent serum made on the basis of highly purified anthracoid globulins has a coloring titer (specific activity) of 1:16. When examining the specificity of the obtained luminescent serum in smears from anthrax agent strains, clear fluorescence was observed with more intense luminescence along the periphery of microbial cells.
\end{abstract}

\section{Introduction}

Anthrax is an acute infectious disease dangerous to animals and humans. In the past, it caused enormous damage to livestock production in many countries of the world and often caused massive diseases of people. [1] At present, anthrax in only found in certain cases and outbreaks, as evidenced by its registration statistics in most countries of the world.

This infection has a global prevalence, not uniformly covering all continents and not registering in just a few island territories [2, 3]. The stability of anthracoid microbe in soil caused by the phenomenal ability of spores to persist for decades contributes to potentially dangerous anthrax areas leading to the development of epizootic and epidemic outbreaks of the disease.

The causative agent exists in two forms: vegetative one in vivo and spore one in the environment, which causes the most important epizootiological and epidemiological characteristics of anthrax. Penetrating into the body, spores multiply into the vegetative forms of B. anthracis, which are the trigger of the infection process. The extreme survival of the spore forms of the pathogen in such an element of the environment as the soil creates favorable conditions for the formation of a natural foci.

Today there are many methods of anthrax diagnostics $[4,5]$. Despite their considerable number, luminescent microscopy, based on the antigen-antibody reaction observed through the combination of antigens with specific antibodies labeled with different fluorescent dyes, is the leading method.
The fluorescent antibody method (FAM) refers to basic indication methods being quite informative, providing fast and reliable detection of the agent at the stages of early diagnostics. Preliminary detention using this method can be given $3-5$ hours after the material is received [6].

Positive results obtained by FAM make it possible to draw preliminary conclusions on the presence of an anthrax agent or its antigens in the biological material and to start taking anti-episotic and anti-epidemiological measures in a timely manner [7].

The purpose of the study was to obtain luminescent serum based on highly purified anthracoid globulins for the diagnostics of an animal anthrax agent.

\section{Materials and methods}

Hyperimmune serum globulins prepared on two types of antigens - protective from strain 55 (VNIIVViM) and capsular from Lange-2 strain at five-fold scheme of introduction of these antigens - were used to make luminescent anthracoid serum.

To obtain the capsular antigen, the Lange- 2 strain was seeded in a special GCI medium and incubated in anaerobic culture apparatus at $370{ }^{\circ} \mathrm{C}$ for $18-20$ hours. The presence of an anthrax capsule, after incubation on a nutrient medium, was studied by staining the Gram and Michin smears. Upon detection of the capsule, the GCI medium was centrifuged at $4000 \mathrm{rpm}$, the precipitated exciter cells were washed 3 times with physiological saline.

The capsule was separated from a bacterial cell by the following method: the resulting precipitate was

* Corresponding author: albert-954@mail.ru 
dissolved in $50 \mu \mathrm{l}$ of distilled water with the addition of $50 \mu \mathrm{l}$ of lysis solution containing $10 \mathrm{mM}$ tris buffer, $\mathrm{pH}$ 6.8, $3 \%$ sodium dodecyl sulfate (SDS) and $0.1 \%$ mercaptoethanol on a shuttle device. Inactivation of the anthrax agent was carried out with $10 \%$ formalin solution.

Then, the suspension of microorganisms with lysis solution was centrifuged at $4000 \mathrm{rpm}$, and the lipopolysaccharide complex in the supernatant was precipitated with ammonium sulfate at room temperature, followed by washing the precipitate 3 times with physiological solution.

The protective anthrax exotoxin antigen cultivated on bicarbonate medium 199 was obtained by filtration through bacterial candles. The antigen was also precipitated with ammonium sulfate at room temperature for 18 hours and washed 3 times.

The antigens received in the above described methods were dissolved in phosphate-buffer saline (FBS), pH 7.2, and each was dialyzed within 48 hours against distilled water for removal of excess content of $\mathrm{NH}^{+}$ions. The antigens were packed into ampoules and used as needed.

Immunization of rabbits was performed fivefold with protective and capsular antigens. The first injection of protective antigen at a dose of $100 \mu \mathrm{g} / \mathrm{ml}$ was introduced intradermally in combination with complete Freund's adjunct along the vertebral column into five points on each side; the second injection of $100 \mu \mathrm{g} / \mathrm{ml}$ capsular antigen was introduced intradermally in combination with incomplete Freund's adjuvant; the third and fourth injections are similar to the second, containing $300-400 \mu \mathrm{g} / \mathrm{ml}$, respectively, of each antigen were introduced on the left and right sides of the vertebral column; the fifth injection - protective and capsular antigen was introduced intravenously at a dose of 500 $\mu \mathrm{g} / \mathrm{ml}$. The interval between injections is $7-10$ days.

Desalting out of globulin fraction from hyperimmune anthracoid serum was carried out with saturated ammonium sulfate solution as follows: the measured volume of serum was placed in a beaker on a magnetic mixer, in an ice bath at $4{ }^{\circ} \mathrm{C}$. After stopping the mixer, a saturated ammonium sulfate solution in a volume equal to half the volume of the serum was pipetted into the serum (saturated ammonium sulfate solution contained $542 \mathrm{~g}$ of salt in $1 \mathrm{~L}$ of distilled water).

After mixing for 20 minutes, it was centrifuged at $10,000 \mathrm{rpm}$. The liquid over the precipitate was removed and the resulting precipitate was dissolved in $0.15 \mathrm{M}$ sodium chloride solution. On the first day the dialysis fluid was changed every four hours, on the next three to four days - once a day until ammonium sulfate completely disappeared.

The completion of dialysis was monitored with $10 \%$ barium chloride solution.

Purification and dilution of globulin fraction proteins was carried out by ion exchange chromatography on a chromatographic column (length $40 \mathrm{~cm}$, diameter $2.5 \mathrm{~cm}$ ) filled with diethylaminoethyl cellulose fibrous polymer.

A column having a diameter of $2.5 \mathrm{~cm}$ was filled with cellulose. The filling was carried out gradually and accurately to a height of $40 \mathrm{~cm}$. The $\mathrm{pH}$ of the starting buffer from the column was then adjusted to $\mathrm{pH}$ 7.2. Very carefully, $10 \mathrm{ml}$ of immunoglobulins were pipetted into the column, previously dialyzed with starting buffer overnight.

The washing was started with $0.01 \mathrm{M}$ phosphate buffer, $\mathrm{pH} 7.2$, and continued in portions with the same buffer thus increasing molarity and decreasing $\mathrm{pH}$. The effluent fractions were collected into fraction collector tubes - $10 \mathrm{ml}$ of each fraction. The protein was determined spectrometrically at a wavelength of $280 \mathrm{~nm}$ according to the formula:

$$
x=\frac{(a * 280)}{1.35},
$$

where $x$ - protein content, $\mathrm{mg} / \mathrm{ml} ; a$ - cultivation.

The resulting anthracoid globulin was labeled with fluorescein isothiocyanate (FITC). To determine the coloring titer of the luminescent anthracoid serum, the colored smears were microscoped under a luminescent microscope using dimethylphthalate and buffered glycerin with various serum dilutions.

The activity of luminescent anthracoid serum was studied in FAM using cultures of vaccine strains of B. anthracis agent: 55 (VNIIVViM), Lange-2, M-71. The specificity was established using B. cereus 8035 and B. subtilis 433 soil bacilli.

\section{Results and discussion}

The modern production of diagnostic products is a single biotechnological system, which consists of successive stages and operations, the number and features of which depend on the type of product manufactured. The main biological raw materials in the production of diagnostic preparations are specific antigens isolated from microbial biomass, and immune serum obtained on their basis. With a variety of methods for extracting specific antigens from microbial cells, a complex of sequential manipulations is necessary.

Currently, for the industrial production of diagnostic products, only ion-exchange chromatography is used or in combination with fractionating agents ethanol, polyethylene glycol, the alcohol method. Immunoglobulins $\mathrm{G}, \mathrm{A}, \mathrm{M}$ are also obtained by chromatography, precipitation with polyethylene glycol, caprylic acid, rivanol-salt, caprylate-alcohol methods, followed by treatment with various reagents. In our case, the purification and dilution of the globulin fraction proteins were carried out by ion exchange chromatography by charge on a chromatographic column (length $40 \mathrm{~cm}$, diameter $2.5 \mathrm{~cm}$ ) filled with a fibrous polymer of diethylaminoethyl cellulose (DEPE cellulose).

The specific activity of purified immunoglobulins was studied in an indirect solid-phase version of enzymelinked immunosorbent assay (ELISA). The solid phase used was 96- alveolar polystyrene plates of VNII Medtechnics (Moscow). The commercial preparation- 
diagnostic immunoglobulins Ig $\mathrm{G}(\mathrm{H}-\mathrm{L})$ of a rabbit labeled with peroxidase manufactured by N.F. Gamaleya Research Institute of Epidemiology and Microbiology was used as anti-acid antibodies labeled with enzymes. An ortho-phenylenediamine substrate was used to detect enzyme activity in the antigen-antibody immune system. The reaction was stopped with a solution of sulfuric acid at a concentration of $0.5 \mathrm{~mol} / \mathrm{l}$.

The results of determining the activity of rabbit hyperimmune blood serum on 14, 21 and 30 days after antigen administration are shown in Table 1.

Table 1. Activity of hyperimmune serum

\begin{tabular}{|c|c|c|c|}
\hline \multirow{2}{*}{ Antigen } & \multicolumn{3}{|c|}{ Antibody titre in EIA, days } \\
\cline { 2 - 4 } & $\mathbf{1 4}$ & $\mathbf{2 1}$ & $\mathbf{3 0}$ \\
\hline Protective & $1: 1024$ & $1: 2048$ & $1: 8192$ \\
\hline Capsular & $1: 128$ & $1: 512$ & $1: 1024$ \\
\hline
\end{tabular}

As can be seen from the data given in the table, the greatest titer of blood serum antibodies is achieved on the 30 day after the administration of anthracoid antigens, wherein the activity of the immune serum to the protective antigen was twice or more (1:8192) compared to the capsular antigen (1:1024). Therefore, this scheme of rabbit hyperimmunization was further taken as the main one in the preparation of diagnostic agents.

The specificity of rabbit serum immunoglobulins was tested in an indirect version of ELISA with antigens from strains B.cereus 8035 and B.subtilis 433. The results of the study of specific hyperimmune serum activity are shown in Table 2 .

Table 2 shows that the antibody titres of rabbits' blood serum to anthracoid antigens (strain M-71 and strain 55 (VNIIVViM) made 1:4096 and 1:8192 respectively. At the same time, the cross-reaction with aerobic soil saprophytes remained in low titers. Based on the obtained results, it can be concluded that the method of rabbit hyperimmunization with a protective-capsular antigen allows obtaining highly active immune serum.

Table 2. Specific activity of capsular-protective immune anthracoid blood serum of rabbits in ELISA

\begin{tabular}{|c|c|}
\hline Antigens & Antibody titre \\
\hline Strain M-71 & $1: 4096$ \\
\hline Strain 55 (VNIIVViM) & $1: 8192$ \\
\hline Strain 8035 & $1: 64$ \\
\hline Strain 433 & $1: 8$ \\
\hline
\end{tabular}

The results of ELISA specific activity of purified immunoglobulins are shown in Table 3.

Table 3. Specific activity of immunoglobulins in ELISA

\begin{tabular}{|c|c|c|c|}
\hline $\begin{array}{c}\text { Protein } \\
\text { concentration } \\
\text { in }\end{array}$ & $\begin{array}{c}\text { Immunoglob } \\
\text { ulin activity }\end{array}$ & \\
\cline { 3 - 4 } $\begin{array}{c}\text { immunoglobul } \\
\text { in, } \mu \mathrm{g} / \mathrm{ml}\end{array}$ & & $\begin{array}{c}\text { B.anthracis, } \\
\text { strain M-71 }\end{array}$ & $\begin{array}{c}\text { B.subtilis, } \\
\text { strain 433 }\end{array}$ \\
\hline
\end{tabular}

\begin{tabular}{|c|c|c|c|}
\hline 25 & $1: 1024$ & $0.65 \pm 0.12$ & $0.02 \pm 0.004$ \\
\hline 50 & $1: 2048$ & $0.87 \pm 0.13$ & $0.09 \pm 0.01$ \\
\hline 100 & $1: 4096$ & $1.20 \pm 0.14$ & $0.19 \pm 0.07$ \\
\hline 200 & $1: 8192$ & $2.02 \pm 0.17$ & $0.21 \pm 0.01$ \\
\hline
\end{tabular}

Note: Difference confidence levels relative to control $(\mathrm{p})$, respectively $\leq 0.05 ; \leq 0.01$ and $\leq 0.001$.

As can be seen from the table, the specific activity of purified immunoglobulins in ELISA is in antibody titer 1:8192 at a protein concentration of $200 \mu \mathrm{g} / \mathrm{ml}$. The specificity coefficient of B.subtilis with the greatest antigen dilution does not exceed OP 0.21 , with the antigen $\mathrm{B}$. anthracis $\mathrm{OP}=2.02$. Consequently, the results of the studies show the specific activity of purified immunoglobulins from hyperimmune anthracoid serum and the prospect of their use for the identification and indication of anthrax agents.

The marking of immunoglobulins was done with fluorescein-5-isothiocyanate (Merck) in the amount of $0.025 \mathrm{mg}$ per $1 \mathrm{mg}$ protein under constant stirring for 6 hours in a refrigerating chamber at $+4{ }^{\circ} \mathrm{C}$. Upon expiry of the indicated period, the excess dye was removed by dialysis against carbonate-bicarbonate buffer. The dialysis was stopped when the dialysis solution remained clear. The coloring working titer of the luminescent serum was determined. A dilution per one above the coloring dilution is considered working.

The specific activity of the obtained luminescent serum was determined by MPA.

Smears of micro-organism cultures were prepared on microscope slides. The smears were air dried and fixed in acetone for 20 minutes. About 1-2 drops of luminescent serum of each dilution were applied to the fixed smears, placed for 30 minutes in a wet chamber at $37{ }^{\circ} \mathrm{C}$, washed with running water for 10 minutes, then lowered into buffered saline for 10 minutes, rinsed with distilled water and dried.

The prepared smears were analyzed under a luminescent microscope. To determine the coloring titer of luminescent anthracoid serum, the colored smears were analyzed under a luminescent microscope using dimethylphthalate and buffered glycerol with various serum dilutions $(1: 2,1: 4,1: 8,1: 16,1: 32,1: 64,1: 128)$.

The maximum dilution of serum at which the glow of microbial cells in 3-4 crosses was observed was considered the coloring titer of serum.

The MPA results concerning the specific activity of luminescent serum are shown in Table 4.

The table shows that the luminescent serum made on the basis of highly purified anthracoid globulins obtained from hyperimmune serum has a coloring titer (activity) of $1: 32$. Half of the coloring titer of serum antibodies, i.e. 1:16, was taken as a working dilution. At the same time, the microorganisms of soil spore-forming bacilli were painted in two crosses by insignificant glow.

Table 4. Activity and specificity of luminescent anthracoid serum

\begin{tabular}{|c|c|c|c|c|c|}
\hline $\begin{array}{c}\text { Serum } \\
\text { dilution }\end{array}$ & $\begin{array}{c}\text { B. } \\
\text { anthracis } \\
\mathbf{5 5}\end{array}$ & $\begin{array}{c}\text { B. } \\
\text { anthracis } \\
\text { M-71 }\end{array}$ & $\begin{array}{c}\text { B. } \\
\text { anthracis } \\
\text { Lange-2 }\end{array}$ & $\begin{array}{c}\text { B. } \\
\text { cereus } \\
\mathbf{8 0 3 5}\end{array}$ & $\begin{array}{c}\text { B. } \\
\text { subtilis } \\
\mathbf{4 3 3}\end{array}$ \\
\hline $1: 2$ & ++++ & ++++ & ++++ & ++ & ++ \\
\hline
\end{tabular}




\begin{tabular}{|c|c|c|c|c|c|}
\hline $1: 4$ & ++++ & ++++ & ++++ & ++ & - \\
\hline $1: 8$ & ++++ & ++++ & ++++ & + & - \\
\hline $1: 16$ & ++++ & ++++ & ++++ & - & - \\
\hline $1: 32$ & +++ & +++ & +++ & - & - \\
\hline $1: 64$ & ++ & ++ & ++ & - & - \\
\hline
\end{tabular}

When examining the specificity of the obtained luminescent serum in smears from strains 55 (VNIIVViM), Lange-2 and anthrax M-71, clear fluorescence was observed with more intense luminescence along the periphery of microbial cells. Strains B. cereus 8035 and B. subtilis 433 gave no glow.

Further research was focused on identifying B. anthracis in a vegetative form in MPA meat with luminescent anthracoid serum. For this purpose, 3 guinea pigs were infected with vaccine capsular-forming strains M-71 ( $2^{\text {nd }}$ Tsinkovsky vaccine). Animals were killed on the $10^{\text {th }}$ day and the samples of meat, parenchymatous organs (spleen, liver, heart, skin) were taken. The pieces of 3-5 g samples were ground, placed in a porcelain mortar and poured with a sterile $0.9 \%$ sodium chloride solution at a rate of 1:10.

The samples were then well triturated with pestle in the same liquid until a uniform mass was obtained. The samples of a sick animal, from pathological material and meat, where the anthrax agent was in a vegetative form, were not warmed up. Therefore, the samples thus prepared were examined in MPA. The results of anthrax agent in meat are shown in Table 5.

Table 5. B. anthracis indication in samples from infected guinea pigs

\begin{tabular}{|c|c|c|c|}
\hline \multirow{2}{*}{ Samples } & \multicolumn{3}{|c|}{ Research techniques } \\
\cline { 2 - 4 } & MPA & ELISA & MPA culture \\
\hline meat & +++ & $6.25 \pm 0.25$ & + \\
\hline liver & ++++ & $7.17 \pm 0.35$ & + \\
\hline spleen & ++++ & $8.25 \pm 0.41$ & + \\
\hline heart & ++ & $4.16 \pm 0.25$ & + \\
\hline skin & + & $1.91 \pm 0.01$ & - \\
\hline Control - intact meat & - & $0.12 \pm 0.001$ & - \\
\hline
\end{tabular}

Note: Difference confidence levels relative to control (p), $\leq 0,05 ; \leq 0,01$ and $\leq 0,001$ respectively.

The studies showed the presence of vegetative anthrax cells in the samples of infected animals. The results of the three methods tested are similar. The most effective indicators were observed in liver and spleen samples.

The luminescent serum made on the basis of highly purified anthracoid globulins reveals vegetative cells of the agent in the working dilution of luminescent serum 1:16. The specific activity of obtained luminescent serum in smears of pathological material anthrax agent has clear fluorescence with intense glow along the periphery of vegetative cells.

\section{Conclusion}

Thus, the developed method of immunization of rabbits with capsular-protective antigen of anthrax agent enables to obtain highly active hyperimmune serum. The specific activity of purified immunoglobulins in ELISA is in antibody titer 1:8192 at protein concentration $200 \mu \mathrm{g} / \mathrm{ml}$.
Consequently, the results of the studies show specific activity of purified immunoglobulins from hyperimmune anthracoid serum. Their subsequent marking with fluorescein-5-isothiocyanate ensures the activity of serum 1:32 with the working dilution of coloring titer of antibodies 1:16. At the same time, the microorganisms of soil spore-forming bacilli have insignificant glow.

The main advantage of MPA is the speed of diagnosis, which varies within 3-5 hours from the start of the study, as well as high specific activity. In the course of analysis of the results of immunoglobulin tests, it was found that the sensitivity of the preparations obtained varies between $1 \times 10^{4}-1 \times 10^{8}$ m.k./ ml; specificity to closely related microorganisms was noted in $75 \%$ relative to vegetative forms and $96.9 \%$ - spore forms.

As a result of a research search carried out on the basis of MPA with obtained FITC-labeled immunoglobulins, $100 \%$ sensitivity was achieved using rabbit-labeled FITC antibodies to the capsule-protective antigen of the anthrax microbe, presumably containing diagnostically significant specific proteins obtained from the culture filtrate of $\mathrm{B}$. anthracis strain Lange 2. The use of experimental immunofluorescence diagnostic preparations designed on the basis of rabbit antisera $\mathrm{B}$. anthracis allows for the identification of vegetative forms of the pathogen from B. cereus in insignificant titers, while FITC-labeled immunoglobulins in the experiment on laboratory animals had strict specificity; the reliability of these diagnostic preparations is ensured by the combined use of two antigens - capsule and protective ones.

\section{References}

1. S.V. Gavrilov, Transduction in anthrax agent, $\mathrm{PhD}$ Dissertation (Saratov, 1990), 154 p.

2. E.A. Gorobets, E.N. Afanasiev, I.S. Tyumentseva, N.F. Vasilenko, Improvement of the method of immune rabbit anthracoid capsule-somatic serum, Original Res. Infectious diseases 3, 42-44 (2008)

3. E.V. Gruz, E.V. Shlyakhov, Method of improving B.anthracis identification, In: Immunodiagnostics and specific prevention of infectious diseases (Chisinau, 1974), pp. 79-84

4. A.K. Galiullin, I.I. Zadorina, S.V. Ivanov et al., Preparation of capsule-protective antianthracoid serum, Sci. notes of the Kazan State Acad. of Veter. Med. named after N.E. Bauman 237(1), 44-47 (2019)

5. A.K. Galiullin, N.S. Sadykov, R.G. Gosmanov, Anthrax of farm animals, Monograph (Lan Publ. house, St. Petersburg, 2019), 224 p.

6. E.A. Gorobets, Development of immunological preparations for anthrax diagnosis, $\mathrm{PhD}$ Dissertation (2008) 168 p.

7. N.G. Ipatenko, Study of cultural-morphological features and virulent properties of B. anthracis released from soil, from sick and fallen animals, pp. 23-27 (Moscow, 1979) 
8. R.N. Lobach, A.S. Abdrashitova, L.V. Sayapina, Test of sibrireulcerative fluorescent immunoglobulins intended for detection of anthrax agent, Biolog. products 6, 15-19 (2013)

9. L.V. Sayapina, R.N. Lobach, A.S. Abdrashitova, Diagnostic effectiveness of immunoglobulins of diagnostic fluorescent anthracoid vegetative adsorbed according to medical tests, Probl. of particul. dangerous infect. 114, 92-96 (2012)

10. K. De Barun, S.L. Bragg, G.N. Sanden, K.E. Wilson, L.A. Diem, C.K. Marston et al., Emerg. Infect. Diseases 8(10), 1060 (2002)

11. F.A. Bedl, M.B. Taylor, C.B. Thorne, Rapid lethal effect in rats of a third compound found upon fractionating the toxine of B. anthracis, J. Bact. 83, 124-128 (1962)
12. B.D. Green et al., Demonstration of a capsule plasmid in B.anthracis, Infect. Immun. 49(2), 291297 (1985)

13. J. Ezzell, T. Abshire, Encapsulation of Bacillus anthracis spores and spore identification, in: Proceedings of the International Workshop on Anthrax, Salisbury Med. Bull. 87, 442 (1999)

14. A. Hoffmaster, R. Meyer, M. Bowen, C. Marston, R. Weyant, G.A. Barnett et al., Emerg Infect. Dis. 8, 1178 (2002)

15. B. Fabien, L. Martine, L. Annie, L. Pierre, M. Michele, Infect. Immun. 72(11), 6313 (2004)

16. D. Fish, R.J. Lincoln, Bacteriol In vivo - produced anthrax toxin, 95(3), 919-924 (1968)

17. D. Kobiler, S. Weiss, H. Levy, Protective Antigen as a Correlative Marker for Anthrax in Animal Models, Amer. Society for Microbiol. 5871-5876 (2006) 